\title{
ПУБЛИЧНОЕ ИМУЩЕСТВО В РОССИИ И ЗА РУБЕЖОМ: ПРОБЛЕМЫ ИДЕНТИФИКАЦИИ И КЛАССИФИКАЦИИ
}

\begin{abstract}
Аннотация: В статье анализируются понятие публичного имущества и критерии его определения в российской и зарубежной доктрине, обобщаются основные различия в используемых подходах. Рассматривается соотношение категорий «публичное имущество» и «общественное достояние». Предлагается и обосновывается новая классификация публичного имущества. The article analyzes the institute of public property and the problem of its identification in the Russian and foreign doctrines. The article also summarizes the main differences in the approaches applied. The author examines the correlation between the categories of «res publicae» and «public domain» and offers a new classification of public property.

Ключевые слова: Юриспруденция, публичное, имущество, собственность, государственное, муниципальное, общественное, достояние, res publicaе, вещъи
\end{abstract}

B сфере публичной собственности многие государства, прежде всего страны континентальной правовой семьи, унаследовали традиции римского права, что проявляется в сходстве терминологии, принятых классификаций имущества, сформированных систем субъективных прав на вещи и др.

В России же система имущественных отношений в $\mathrm{XX}$ в. дважды подвергалась революционным изменениям, результатом которых явился весьма самобытный и противоречивый институт публичной собственности, впитавший в себя и наследие советского периода со свойственной ему «особостью» государственного имущества, и возрожденные классические традиции частного права, и отдельные элементы передового зарубежного опыта, и отечественные нововведения последних лет.

В итоге в российской науке не сложилось единообразия в определении понятия публичного имущества, его критериев и разновидностей, а законодатель в принципе избегает данного термина. Очевидно, что без решения этих базовых вопросов вряд ли удастся сформировать в окончательном виде современную доктрину публичной собственности, а также произвести качественное совершенствование соответствующей нормативно-правовой базы в рассматриваемой сфере, которая, к сожалению, продолжает ассоциироваться у многих сограждан с коррупцией, бюрократической волокитой и фатальной неэффективностью.

\section{1. Понятие публичного имущества и его критерии в России и за рубежом}

В соответствии с господствующим в России подходом публичное имущество отождествляется с объектами государственной и муниципальной собственности. Исторически имущество государства и имущество муниципалитетов (коммун, муниципий, общин) фор- мировалось различными путями ${ }^{1}$, однако на сегодня эти категории объектов, по крайней мере в России, максимально сблизились и включены в единое правовое поле. Этот вывод не ставит под сомнение самостоятельность местного самоуправления и обособленность его имущественной базы, а лишь подчеркивает, что с точки зрения методологии и правового режима вряд ли объекты муниципальной собственности отличаются от федеральной или региональной собственности существеннее, чем, скажем, объекты региональной собственности от федеральной. Другими словами, все эти отличия не нарушают качественного единства государственного и муниципального имущества в рамках универсальной категории «публичное имущество».

Таким образом, при определении публичного имущества используется сугубо субъектный критерий, а термины «публичное имущество» и «объекты публичной собственности» трактуются в качестве синонимов ${ }^{2}$.

\footnotetext{
${ }^{1}$ Говоря об истоках муниципальной собственности, мы прежде всего имеем в виду римское право. Н.П. Карадже-Искров пишет, что публичный характер общин изначально был для римлян не вполне ясен, и поэтому возникали сомнения в существовании общинных публичных вещей. Однако более поздние источники римского права не оставляют сомнений в принадлежности публичных вещей не только государству, но и общинам (Карадже-Искров Н.П. Публичные вещи. Вып. 1. Иркутск, 1927. С. 53-54, 59).

См. также: Азаревич Д.И. Система римского права: Университетский курс. Т. І. СПб., 1897. С. 140-144; Римское частное право: Учеб. / Под ред. И.Б. Новицкого, И.С. Перетерского. М., 2004 (СПС «КонсультантПлюс»). Абз. 1152-1159 (автор главы - В.А. Краснокутский).

${ }^{2}$ В данной статье мы не затрагиваем проблематики имущественных прав, которые в науке гражданского права принято относить к имуществу, но не к объектам вещных прав. За рамками нашего внимания останутся и спорные вопросы возможного расширения понятий вещей и имущества в публичном праве за счет включения в их объем таких явлений, которые не укладываются
} 


\section{Право и политика $6(162) \cdot 2013$}

Схожий субъектный критерий может быть обнаружен в правовых системах и других стран на постсоветском пространстве, в ряде случаев с поправкой на отсутствие самостоятельной муниципальной формы собственности. Например, в Беларуси государственное имущество состоит из объектов республиканской собственности собственности Республики Беларусь, а также объектов коммунальной собственности - собственности административно-территориальных единиц ${ }^{3}$. Аналогичным образом в Казахстане государственное имущество подразделяется на республиканское и коммунальное 4 . К данным группам объектов собственности зачастую применяется термин «публичное имущество».

Однако субъектный критерий определения публичного имущества (объектов публичной собственности), господствующий в современной российской правовой системе, не является общепринятым в зарубежных правопорядках, не имеет он достаточной опоры и на исторические традиции. Напомним, что в подавляющем большинстве стран романо-германского права состав имущества, принадлежащего государству и другим лицам публичного права, признается неоднородным: среди него выделяются особые объекты публичного назначения, правовой режим которых регламентируется по преимуществу не гражданским, а публичным (административным) законодательством. Причем смысл обособления такого имущества заключается в его противопоставлении обыкновенным объектам частноправовой собственности, принадлежащим государству (и некоторым других лицам) и подчиненным гражданско-правовому порядку. Именно по отношению к указанному имуществу применяются термины «объекты публичной собственности» («публичные домены») либо «публичные вещи»:

- $\quad$ в римском праве публичные вещи (res publicae) обособлялись на основе субъектно-функиионального критерия: принадлежали государству или общинам и предназначались для общественного использования ${ }^{5}$.

в гражданско-правовую трактовку вещей (атмосферный воздух, воздушное пространство, радиочастоты, Интернет и т п.), имея в виду релевантный опыт Германии (Wolff H. J., Bachof O., Stober R. Verwaltungsrecht. Bd II. 6. Aufl. München, 2000. § 75), Франции (Auby J.-M., Bon P., Auby J.-B. Droit administratif des biens. $4^{e}$ éd. P.: Dalloz, 2003. P. 144-148), и др. стран континентального стран, а также схожие тенденции в англо-саксонском праве (Rose C.M. Romans, Roads, and Romantic Creators Traditions of Public Property in the Information Age // Law and Contemporary Problems. 2003. Vol. 66).

${ }^{3}$ См. п. 1 ст. 215 Гражданского кодекса Республики Беларусь 1998 г. // http://www.pravo.by.

${ }^{4}$ См. ст. 2 Закона Республики Казахстан от 1 марта 2011 г. № 413$\mathrm{IV}$ «O государственном имуществе» // http:// http://online.zakon.kz.

${ }^{5}$ Res publicae имеют в источниках римского права несколько значений и в одних случаях указывают на имущество, «при-
Этот подход после рецепции римского права был воспринят европейскими правопорядками, в том числе дореволюционной Россией ${ }^{6}$, однако впоследствии существенно эволюционировал: функциональный критерий заметно расширился и в ряде государств приобрел самостоятельное значение;

- $\quad$ в странах романского права публичные домены (domaine public), признаваемые объектом особой публичной собственности и противопоставленные объектам частноправовой собственности (domaine privé), определяются также на основе субъектнофункционального критерия, охватывая не только имущество общего пользования, но и обеспечивающее нужды публичных служб (Франция

надлежащее римскому народу», а в других - на имущество, «принадлежащее римскому народу и назначенное для публичного пользования». Поэтому с точки зрения разграничения с патримониальным (фискальным, финансовым) имуществом государства и общин, которое находилось в гражданском обороте и подчинялось частноправовому порядку, более точен термин res publicae publico usui destinatae, который характеризует особую связь с указанными субъектами, с одной стороны, и назначение для публичного пользования - с другой (см.: Гинс Г.К. Право на предметы общего пользования (к проблеме взаимоотношений общих и частных интересов в гражданском праве) // Известия Юридического Факультета в г. Харбине. Т. 1. Харбин, 1925. С. 23-45; Карадже-Искров Н.П. Указ. соч. С. 1-2; Барон Ю. Система римского гражданского права. Вып. 1. Кн. І: Общая часть / Пер. Л. Петражицкого. М., 1898. С. 100-101; Гримм Д.Д. Лекции по догме римского права. СПб., 1916. С. 33-34; Зом Р. Институции. История и система римского гражданского права. Ч. 2: Система. Вып. І: Общая часть и вещное право / Пер. Н. Кесслер; под. ред. А.Н. Беликова. Сергиев Посад, 1916. С. 236-237 и др.; Ельямевич В.Б. Юридическое лицо, его происхождение и функции в римском частном праве. СПб., 1910. С. 39; Пухта Г.Ф. Курс римского гражданского права. Т. I / Пер. проф. Рудорффа. M., 1874).

Аналогичного подхода придерживаются и современные зарубежные исследователи (см., например: Derecho de los Bienes Públicos / Dir. Julio V. González García. 2a ed. Valencia: Tirant lo Blanch, 2009. P. 40 (автор главы - prof. M.S. Vallejo)).

${ }^{6}$ См. дореволюционную литературу как по административному праву (Евтихиев И.И. Теория публично-вещного права (обзор литературы) // Вопросы административного права. Кн. I / Под ред. А.И. Елистратова. М., 1916. С. 144-151; Елистратов А.И. Основные начала административного права. М. 1914. С. 153-155 и др.), так и гражданскому праву (Анненков К.Н. Система русского гражданского права. Т. 1: Введение и общая часть. СПб., 1899. С. 350 , 358-359, 379-395; Дювернуа Н.Л. Чтения по гражданскому праву. Т. 2: Учение о вещах. Учение о юридической сделке / Под ред. и с предисл. В.А. Томсинова. М., 2004. С. 16-22; Победоносиев К.П. Курс гражданского права. Первая часть: Вотчинные права. М., 2002. С. 98-102; Шершеневич Г.Ф. Учебник русского гражданского права. Т. 1. М., 2005. § 14 и др.).

${ }^{7}$ См. прежде всего курсы административно-имущественного права Франции: Morand-Deviller J. Droit administratif des biens. $6^{\mathrm{e}}$ éd. P.: Montchrestien, 2010; David-Beauregard-Berthier O. de. Droit administratif des biens. 6e éd. P.: Gualino, 2010; Guettier Ch. Droit administratif des biens. P.: Presses Universitaires de France, 2008; 
Испания ${ }^{8}$, государства Латинской Америки и др.). Некоторая специфика присутствует в законодательстве Италии, где с точки зрения юридического режима к объектам публичной собственности, выделяемым по субъектно-функциональному критерию, примыкает имущество частных лиц, предназначенное для публичного использования (i beni privati di interesse pubblico $)^{9}$;

- $\quad$ в современном германском праве, которое не признает феномен публичной собственности, выделяются категория публичных вещей (öffentlichen Sachen), определяемая на основе только функиионального критерия - служения общему благу. В связи с этим допускается принадлежность публичных вещей частным лицам ${ }^{10}$. Несмотря на определенное влияние французской доктрины, немецкая концепция в настоящее время принята в Швейцарии ${ }^{11}$.

Таким образом, субъектный критерий определения публичного имущества, утвердившийся в российской правовой системе, является весьма самобытным с точки

Auby J.-M., Bon P., Auby J.-B. Op. cit.; Godfrin Ph. Op. cit.; Peiser $G$. Droit administratif des biens. $18^{\mathrm{e}}$ éd. P.: Dalloz, 2005; Lavialle $C r$. Droit administratif des biens. P.: Presses Universitaires de France, 1996; Gaudemet Y. Traité de droit administrative. T. 2. Droit administratif des biens. $13^{\mathrm{e}}$ éd. P.: Librairie générale de droit et de jurisprudence (L.G.D.J), 2008.

Рассматриваемое деление присутствует не только в науке, но и законодательстве Франции - см. прежде всего Общий кодекс собственности лиц публичного права 2006 г. (Code général de la propriété des personnes publiques) // http://www.legifrance.gouv.fr.

${ }^{8}$ См., например: Derecho de los bienes públicos / Dir. Julio V. González García. $2^{\mathrm{a}}$ ed.; Derecho de los bienes públicos. 4 Tomos / Dirs. L. Parejo Alfonso, A. Palomar Olmeda. Madrid: Editorial Aranzadi, S. A., 2009; Sánchez Morón M. Los bienes públicos (régimen jurídico). Madrid: Tecnos, 1997; Morillo-Velarde Pérez J.I. Dominio Público. Madrid: Trivium, 1992; Jiménez Blanco Carrillo A. Cuadernos de Derecho para Ingenieros. Derecho de bienes públicos. Madrid: La Ley, 2009. См. также: Закон Испании об имуществе публичной администрации 2003 г. (Ley 33/2003, de 3 de noviembre, del Patrimonio de las Administraciones Públicas) // http://noticias.juridicas.com.

${ }^{9}$ См., например: Centofanti $N$. I beni pubblici: tutela amministrativa e giurisdizionale. Milano: Giuffrè Editore, 2007. P. 297-356.

${ }^{10}$ См., например: Papier H.-J. Recht der öffentlichen Sachen. 3. Aufl. Berlin: De Gruyter, 1998. S. 6.

Собственно об этом писал еще Й. Бирман в начале XX в. (Biermann J. Die öffentlichen Sachen. Giessen, 1905), однако оставался в меньшинстве (см.: Каражде-Искров Н.П. Указ. соч. С. 29-31). Впрочем, данная точка зрения достаточно быстро утвердилась (см., например: Эннекцерус Л., Кипn T., Вольф М. Курс германского гражданского права. Т. І. Полутом 2: Введение и общая часть / Пер. с нем. И.Б. Новицкого, Г.Н. Полянской, В.А. Альтшулера; под ред. Д.М. Генкина, И.Б. Новицкого. М., 1950 (перевод с немецкого издания 1931 г.). С. 53, 56). В настоящее время этот подход является господствующим.

${ }^{11}$ См., например: Häfelin U., Müller G., Uhlmann F. Allgemeines Verwaltungsrecht. 6. Aufl. Zürich: Dike Verlag AG, 2010. S. 531. зрения традиций романо-германского права. Тем более что к числу публичных собственников затруднительно причислять так называемые публичные юридические лица (как это имеет место, например, во Франции, Испании), поскольку в России соответствующий институт законодательно не закреплен ${ }^{12}$.

Вместе с тем в последние годы все более отчетливо стал проявляться не только субъектный, но и функциональный критерий, однако не в том смысле, что в составе объектов собственности государства и муниципальных образований обособляется имущество публичного назначения (как это имеет место в странах континентальной правовой семьи), а в том, что за всеми объектами государственной и муниципальной собственности признается подобное назначение. Это связано с реализацией концепции административной реформы, в соответствии с которой Российская Федерация, ее субъекты и муниципальные образования должны сохранять и управлять только такими объектами, которые обеспечивают государственные и муниципальные функции ${ }^{13}$.

В результате субъектный критерий как бы дополняется функциональным, исключая появление в собственности государства и муниципальных образований «частноправового» имущества, которое не предназначено для служения интересам общественной пользы и квалифицируется как «непрофильное». Данные процессы сопровождаются восполнением образовавшихся в 90-х годах минувшего столетия пробелов публично-правового регулирования отношений государственной и муниципальной собственности, наличие которых давало повод для того, чтобы сводить «публичность» имущества сугубо к указанию на его обладателей.

В контексте подобных преобразований российский подход к определению публичного имущества нельзя воспринимать негативно лишь на том основании, что он не соответствует европейским традициям, основанным на дихотомии объектов собственности, принадлежащих государству и другим лицам публичного права, поскольку в значительной степени это именно следование традиции, результат постепенной эволюции учений о публичной собственности (публичных вещах) на Западе. Показательно, что в современной французской науке различие между domaine public и domaine privé подвергается серьезной критике, так как основной критерий для разграничения - наличие или отсутствие общественной пользы

\footnotetext{
${ }^{12}$ Проблематика публичных юридических лиц и правового режима их имущества составляет отдельный предмет исследования (см. подробнее: Винницкий А.В. О необходимости законодательного закрепления института юридических лиц публичного права // Журнал российского права. 2011. № 5).

${ }^{13}$ См. подробнее: Винницкий А.В. Государственная собственность в административном праве. М., 2010. С. 19-41.
} 


\section{Право и политика $6(162) \cdot 2013$}

- достаточно спорен: в частном имуществе государства обнаруживаются серьезные публичные интересы, а в сферу отношений публичной собственности все сильнее приникают частные начала ${ }^{14}$.

В любом случае вряд ли проходится ожидать, что российский законодатель изменит подход к проблеме, и государственное и муниципальное имущество будет разделено на публичное и непубличное (частное). Исходя из ч. 2 ст. 8 Конституции РФ, с учетом толкования данной нормы Конституционным Судом РФ, публичная собственность объединяет все государственное и муниципальное имущество и в этом смысле противопоставляется частной собственности - собственности граждан и юридических лиц ${ }^{15}$.

Однако для целей сравнительно-правового анализа важно установить, каким образом соотносятся правовые режимы государственного и муниципального имущества в России и за рубежом. Представляется, в юридической системе координат публичное имущество «по-российски» занимает некое промежуточное положение между объектами публичной и частной собственности в европейских правопорядках. При этом отдельные категории государственного и муниципального имущества в России (например, изъятые из оборота природные объекты) по своему правовому режиму в большей степени сближаются с классическими публичными доменами, другие, напротив, тяготеют к объектами частноправовой собственности государства (например, акции в хозяйственных обществах).

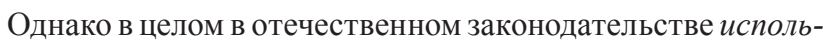
зуется методологически единый юридический инструментарий для регулирования отношений государственной и муниципальной собственности, а также во многом универсальный механизм управления соответствующим имуществом. Учитывая это, для дифференциации правового режима различных категорий публичного имущества необходимо руководствоваться иными критериями, которые опирались бы как на отечественные правовые традиции, так и на релевантный опыт зарубежных правопорядков.

\section{2. К вопросу о терминологии:} публичное имущество или общественное достояние?

В отношении публичного имущества в целом либо отдельной его части нередко употребляются термины «общенародное достояние», «общественное достояние», «национальное достояние», «национальное богатство» и т. п. Концепция общенародного достояния была осо-

${ }^{14}$ См. подробнее: Auby J.-B., Auby J.-M., Bon P. Op. cit. P. 17-22, 169-186.

${ }^{15}$ См., например, постановления КС РФ от 20 декабря 2010 г. №22-П (СЗ РФ. 2011. № 1. Ст. 264), от 30 июня 2006 № 8-П (С3 РФ. 2006. № 28. Ст. 3117) и др. бенно распространена в советский период и опиралась на действовавшие в то время нормативные акты, где использовалась названная категория ${ }^{16}$. Общенародным достоянием объявлялись все объекты государственной собственности ${ }^{17}$. Данная концепция с начала $90-$ х годов XX в. неоднократно подвергалась содержательной критике в связи с неоправданным разграничением экономического и юридического собственников имущества, мнимостью преимуществ и юридической бессодержательностью анализируемой конструкции ${ }^{18}$.

Новейшее законодательство, за редкими исключениями $^{19}$, отказалось от употребления категории «общенародное достояние». Однако в науке этот термин по-прежнему используется, однако уже в обновленном значении - применительно к определенной части публичного имущества. Так, по мнению В.П. Мозолина, у государства на праве собственности могут быть объекты двух видов (категорий): во-первых, это специфическая категория объектов, предназначенных для общего пользования людей в обществе или для обслуживания потребностей самого государства; во-вторых, это объекты производственного назначения, которые могут находиться и в частной собственности граждан и юридических лиц. При этом в отношении первой категории автор использует термин «народное достояние» («народная собственность»), акцентируя, что речь не идет о монополистической общенародной (государственной) собственности советского периода как особой привилегированной форме собственности; общенародное достояние в условиях рыночной экономики охватывает лишь указанную выше специфическую часть государ-

\footnotetext{
${ }^{16}$ См., например, ст. 5, 6 Конституции СССР 1936 г.; ст. 11, 11.1 Конституции РСФСР 1977 г.; п. 5 Декларации СНД РСФСР от 12 июня 1990 г. «О государственном суверенитете Российской Советской Федеративной Социалистической Республики» (Ведомости СНД и ВС РСФСР. 1990. № 2. Ст. 22); ст. 6, 20 Закона РСФСР от 24 декабря 1990 г. № 443-І «О собственности в РСФСР» (Ведомости СНД и ВС РСФСР. 1990. № 30. Ст. 416) и т. д.

${ }^{17}$ См., например: Толстой Ю.К. Содержание и гражданско-правовая защита права собственности в СССР. М., 1955. С. 22-30.

${ }^{18}$ См., например: Иванов А.А. Общее (народное) достояние и право государственной собственности // Правоведение. 1990. № 5. Обзор мнений по вопросу употребления в законодательстве и доктрине термина «общественное достояние» приводится, в частности, в работе В.Г. Голубцова (Голубцов В.Г. Сочетание публичных и частных начал в регулировании вещных отношений с участием государства. СПб., 2005. С. 125-142).

19 Термин «достояние» продолжает применяться, в частности, в отношении находящихся в государственной собственности объектов животного мира (ст. 4 Федерального закона от 24 апреля 1995 г. № 52-Ф3 «О животном мире» // СЗ РФ. 1995. № 17. Ст. 1462), земель особо охраняемых природных территорий (п. 2 ст. 95 Земельного кодекса РФ), объектов культурного достоянию народов Российской Федерации (ст. 34 Закона РФ от 9 октября 1992 г. № 3612-I «Основы законодательства Российской Федерации о культуре» // РГ. 1992. 17 нояб.).
} 


\section{Государственные институты и правовые системы}

ственного имущества ${ }^{20}$. В.Г. Голубцов схожим образом обосновывает выделение двух разновидностей государственного имущества: объектов исключительной государственной собственности и объектов коммерческой собственности государства ${ }^{21}$. В отношении первой категории имущества С.А. Сосна оперирует понятием общественного достояния ${ }^{22}$, а В.Д. Мазаев - близким по содержанию понятием «национальное достояние» ${ }^{23}$. Разница в приведенных подходах в значительной степени приобретает терминологический характер, что весьма красноречиво подтверждает позиция В.А. Тархова и В.А. Рыбакова, которые предлагают ввести понятие «объекты исключительной собственности государства - общественного достояния» ${ }^{24}$.

Очевидно, что общенародное достояние в подобной интерпретации фактически отождествляется с рассмотренным выше феноменом публичной собственности в странах романского права. В связи с этим примечательно, что французский термин domaine public, испанский dominio público, португальский domínio público, итальянский demanio pubblico могут переводиться не только как публичная собственность или публичные домены, но и как «общее достояние», «общественное достояние», «всеобщее достояние» или «общенародное достояние». Надо полагать, здесь, как и во многом другом, проявляются римско-правовые традиции. В частности, Гай характеризовал res publicae (от которых произошла категория публичной собственности) не как имущество отдельных граждан, а как имущество совокупности - его обладателем являлся римский народ в целом ${ }^{25}$.

${ }^{20}$ См., в частности: Мозолин В.П. Право собственности в Российской Федерации в период перехода к рыночной экономике. М., 1992. С. 126-146. Отметим, что В.П. Мозолин в отношении народного достояния в равной степени использует термин «исключительная собственность государства» (там же).

${ }^{21}$ Голубиов В.Г. Указ. соч. С. 124-141. Отметим, что автор не ограничивает специфику объектов исключительной государственной собственности сугубо изъятием соответствующего имущества из оборота, а предлагает такую его характеристику и классификацию, которая в значительной степени соответствует феномену публичных доменов в их традиционном понимании. Вместе с тем данный термин не вполне удачен, ибо он не охватывает сопоставимые объекты, находящиеся в муниципальной собственности. Поэтому по крайней мере следовало бы говорить об объектах исключительной публичной собственности.

${ }^{22}$ См. подробнее: Сосна С.А. О концепции общественного достояния // Государство и право. 1996. № 2. С. 55-57.

${ }^{23}$ Мазаев В.Д. Публичная собственность в России: конституционные основы. М., 2004. С. 58-63.

${ }^{24}$ Тархов В.А., Рыбаков В.А. Собственность и право собственности. М., 2007 (СПС «КонсультантПлюс»). Абз. 807-820.

${ }^{25}$ Впрочем, римский юрист подчеркивает, что имущество принадлежит всем гражданам в их организации в единый народ, каждый же отдельный гражданин прав на это имущество не имеет (см.: Ельямевич В.Б. Указ. соч. С. 40-41).
Представляется, что использование термина «общественное достояние» в современной российской правовой системе имеет смысл только в том случае, если таким образом можно указать на наличие конкретных юридических качеств у строго определенной категории объектов. Подобных качеств, на наш взгляд, не обнаруживается.

Во-первых, высказываются мнения об особенностях субъектного состава отношений по поводу объектов общественного достояния. В частности, в советский период декларировалось, что их обладателем является народ, при этом отдельные граждане выступает одновременно и в качестве управомоченных, и в качестве обязанных лиц ${ }^{26}$. В настоящее время эту концепцию активно развивает В.Д. Мазаев, утверждая, что в конституционных правоотношениях собственник публичного имущества народ, который уполномочивает публичное образование на распоряжение и управление данным имуществом ${ }^{27}$. В соответствии с другим подходом, который обосновывали некоторые авторитетные европейские ученые XIX начала ХХ в. (Ж.-Б.-В. Прудон ${ }^{28}$, Л. Дюги ${ }^{29}$, Р. фон Иеринг, Ф.Л. Келлер $\left.{ }^{30}\right)$, публичные домены в принципе не являются объектом права собственности. Однако подобные взгляды в целом уступили место «собственническому» подходу (Г. Дернбург ${ }^{31}$, М. Ориу ${ }^{32}$, Р. Фернандес де Веласко ${ }^{33}$ и др.) еще в конце XIX - начале XX в. ${ }^{34}$ Представляется, что с

\footnotetext{
${ }^{26}$ Толстой Ю.К. Указ. соч. С. 29.

${ }^{27}$ Мазаев В.Д. Указ. соч. С. 152-155, 190-198, 58-64 и др.
}

${ }^{28}$ Proudhon J.-B.-V. Traité du domaine public, ou de la Distinction des biens considérés principalement par rapport au domaine public. 5 vol. Dijon: Chez Victor Lagier, 1833-1834.

29 Дюги Л. Конституционное право. Общая теория государства / Пер. А. Ященко, В. Краснокутского, Б. Сыромятникова, с предисл. к рус. пер. П. Новгородцева. М., 1908. С. 145-151.

${ }^{30}$ Biermann M. Das Staatseigentum an öffentlichen Sachen im Gemeingebrauch in der ersten Hälfte des 19. Jahrhunderts: die Theorie des reinen Hoheitsrechts an den öffentlichen Sachen von Rudolph von Jhering und Friedrich Ludwig Keller im Zusammenhang mit dem Baseler Schanzenstreit von 1859/62. Frankfurt am Main: Peter Lang, 2009.

${ }^{31}$ Дернбург Г. Пандекты. Т. 1: Общая часть / Пер. Г. фон Рехенберга, под рук. и ред. П. Соколовского. М., 1906. С. 192-194.

${ }^{32}$ Hauriou M. Précis de Droit Administratif et de droit public general. $4^{e}$ éd. París: L. Larose, 1900. P. 608-673.

33 Fernández de Velasco R. Naturaleza jurídica del dominio público, según Hauriou. Aplicacióna la legislación española // Revista de Derecho Privado. 1921. P. 230-236.

34 Отметим, что «антисобственническая» концепция остается популярной в правовой доктрине таких государств, как Испания (см.: Derecho de los bienes públicos / Dir. Julio V. González García. $2^{a}$ ed. P. 59, 69-72), а также Чили (см.: Vergara Blanco A.Panorama general del Derecho Administrativo Chileno // El Derecho Administrativo Iberoamericano (Estudios y Comentarios, № 9) / Dir. S. González-Varas Ibáñez, Coord. F. Villalba Pérez. Granada (España): Instituto Nacional de Administración Pública, Unión Iberoamericana de Municipalistas, 2005. P. 179). 


\section{Право и политика $6(162) \cdot 2013$}

точки зрения действующего российского законодательства собственником рассматриваемых объектов могут и должны считаться лишь публично-территориальные образования. Подходы, основанные на признании народа обладателем общественного достояния либо непризнании его объектом права собственности в принципе, отражают уже пройденные этапы развития учений о публичной собственности и не укладываются в реалии правового регулирования.

Во-вторых, сторонники концепции общественного достояния указывают на серьезные особенности правового режима соответствующих объектов. В связи с этим В.О. Лучин пришел к справедливому выводу, что в федеральном законодательстве термин «достояние» применяется преимущественно в тех случаях, когда необходимо подчеркнуть важность и уникальность соответствующих объектов (природных ресурсов, культурных, исторических, археологических ценностей, животного мира, информационных ресурсов) и тем самым установить для собственника указанных объектов дополнительные ограничения в интересах общества; при этом характеристика соответствующего объекта как достояния народа является по сути обоснованием для установления особенностей правового режима такого объекта, в том числе в части, касающейся прав собственности на него ${ }^{35}$. Однако необходимо отдавать отчет, что границы и разновидности общественного достояния четко установить невозможно. В частности, данное понятие не тождественно понятию объектов исключительной государственной (публичной) собственности, многие из которых вряд ли могут быть определены в качестве «достояния». В целом применительно к объектам так называемого общественного достояния не сформировано единого правового режима с конкретным содержанием ни в законодательстве, ни в доктрине. И такой режим, по нашему убеждению, не может быть сформирован в России в отсутствие официального деления имущества государства и муниципальных образований на объекты публичной и частной собственности, как это имеет место во Франции, Испании и некоторых других странах.

Таким образом, концепция «общенародного достояния» обладает определенным научным, но не прикладным значением: во-первых, для объяснения социальной сущности государственного и муниципального имущества и отдельных его разновидностей; во-вmopblx, для понимания исторических процессов формирования современных категорий публичного имущества и публичной собственности в России и за рубежом; в-третьих, для оценки отдельных вопросов конституционно-правового

\footnotetext{
${ }^{35}$ См.: Особое мнение Судьи Конституционного суда РФ В.О. Лучина к Постановлению КС РФ от 7 июня 2000 г. № 10-П // С3 РФ. 2000. № 25. Ст. 2728.
}

значения, при решении которых границы понятия права собственности могут раздвигаться в сравнении с гражданско-правовым субъективным правом собственности ${ }^{36}$. Кроме того, правопритязания населения на публичное имущество приобретают юридические очертания применительно к объектам общего пользования; причем именно потому, что такие объекты обеспечивают реализацию конституционных прав личности. Однако и здесь граждане выступают не как собственники, а как субъекты ограниченного публично-вещного права и в определенном смысле противопоставлены юридическому собственнику - государству или муниципальному образованию.

Что касается особенностей правового режима, которые приписываются объектам общественного достояния, они вполне могут быть учтены в рамках такой классификации публичного имущества, которая в большей степени отвечала бы действующему российскому законодательству и формирующейся современной доктрине публичной собственности.

\section{3. Недостаточность частноправовой классификации публичного имущества}

Наукой гражданского права на основе римско-правовых традиций предложена весьма развернутая классификация объектов собственности (вещей), которая в значительной степени нашла отражение в действующем законодательстве: (1) движимое и недвижимое имущество; (2) вещи потребляемые и непотребляемые; (3) вещи, индивидуально определенные, и вещи, определенные родовыми признаками; (4) вещи делимые и неделимые; (5) главные вещи и принадлежности; (6) вещи одушевленные и неодушевленные. Кроме того, по различным критериям могут выделяться категории некоторых специфических объектов: деньги, ценные бумаги, плоды, продукция и доходы, имущественные комплексы, сложные вещи и т. д. ${ }^{37}$

Все приведенные выше классификации имеют универсальное, частноправовое значение, поскольку не зависят от фигуры собственника. При этом цивилистика практически не предлагает какой-либо отдельной дифференциации правового режима публичного имущества ${ }^{38}$, по-видимому,

\footnotetext{
${ }^{36}$ Гипотезу о возможном расхождении конституционно-правового и гражданско-правового содержания права собственности высказал Г.А. Гаджиев (см.: Право собственности: актуальные проблемы / Отв. ред. В.Н. Литовкин, Е.А. Суханов, В.В. Чубаров. М., 2008 (СПС «КонсультантПлюс»). Абз. 124-125).

${ }^{37}$ См., например: Гражданское право. В 4 т. Т.2: Вещное право. Наследственное право. Исключительные права. Личные неимущественные права: Учеб. / Под ред. Е.А. Суханова. М. 2008 (СПС «КонсультантПлюс»). Абз. 257-258.

${ }^{38}$ В качестве определенного исключения можно привести деление публичного имущество на казенное и закрепленное за государственными и муниципальными предприятиями и учреждениями.
} 
руководствуясь весьма распространенным мнением о том, что форма собственности должна трактоваться сугубо в контексте указания на субъект данного вещного права ${ }^{39}$.

В результате в литературе по гражданскому праву, а вслед за ней и в работах по иным дисциплинам вопросы об объектах публичной собственности исследуются, как правило, с использованием перечисленных выше критериев, которые дополняются дифференциацией вещей исходя из субъекта собственности: федеральное имущество, региональное имущество и муниципальное имущество.

Пожалуй, единственный критерий разделения имущества, который имеет выход на проблематику публичного права и специфику объектов государственной и муниципальной собственности - это дифференциация имущества исходя из его оборотоспособности (ст. 129 Гражданского кодекса РФ, далее - ГК РФ). С этих позиций объекты государственной и муниципальной собственности могут быть разделены на следующие группы: (1) публичное имущество, изъятое из оборота - объекты исключительной государственной собственности; (2) публичное имущество, ограниченно оборотоспособное; (3) принадлежащие публичному собственнику объекты, потенциально находящиеся в свободном гражданском обороте.

Современное гражданское законодательство предусматривает, что виды имущества, которые могут находиться только в государственной собственности, определяются законом (п. 3 ст. 212 ГК РФ). Изначальной основой для выявления подобных объектов были Приложения 1 и 2 к Постановлению Верховного Совета РФ от 27 декабря 1991 г. № 3020-I «О разграничении государственной собственности в Российской Федерации на федеральную собственность, государственную собственность республик в составе Российской Федерации, краев, областей, автономной области, автономных округов, городов Москвы и Санкт-Петербурга» ${ }^{40}$. Однако многие из объектов, перечисленных не только в Приложении 2 (объекты, относящиеся к федеральной собственности, которые могут передаваться в региональную собственность), но и в Приложении 1 (объекты, относящиеся исключительно к федеральной собственности), были приватизированы в 90-х годах минувшего века (пред-

Несмотря на то что данная классификация активно используется для дифференциации механизмов публичного администрирования, в значительной степени она преследует частноправовые цели, поскольку служит основой для разграничения вещных прав на публичное имущество, а также форм участия публично-правовых образований в гражданских правоотношениях (непосредственной и опосредованной).

${ }^{39}$ См., в частности: Щенникова Л.С. Вещные права в гражданском праве России. М., 1996. С. 24; Суханов E.A. Правовая форма экономических отношений // Гражданское право России - частное право. М., 2008. С. 21-22.

${ }^{40}$ Ведомости СНД и ВС РСФСР. 1992. № 3. Ст. 89. приятия топливно-энергетического комплекса, электроэнергетики, железнодорожного и воздушного транспорта и др.). По этой причине указанный нормативный акт, хотя и называет некоторые объекты исключительной государственной собственности, реально не содержит соответствующего перечня, поскольку его принятие было продиктовано необходимостью разграничить единый фонд государственного имущества (в частности, для целей его возможной приватизации), а не устанавливать ограничения оборотоспособности перечисленных в нем объектов публичной собственности ${ }^{41}$.

На сегодняшний день к объектам, изъятым из оборота, отнесены, в частности:

1. участки недр, а также находящиеся в общем пользовании водоемы, лесные и земельные участки;

2. земельные участки, занятые воинскими и гражданскими захоронениям, а также некоторыми иными принадлежащими Российской Федерации объектами (ст. 27 Земельного кодекса РФ);

3. наркотические и психотропные вещества, включенные в соответствующий список ${ }^{42}$;

4. химическое оружие, объекты по хранению и уничтожению химического оружия ${ }^{43}$;

5. ядерные материалы в соответствии с утвержденным перечнем ${ }^{44}$;

6. космические аппараты и объекты наземной космической инфраструктуры, относящиеся к спутниковым навигационным системам и создаваемые за счет средств федерального бюджета ${ }^{45}$;

7. государственные эталоны единиц времени и средства передачи информации о точном значении московского времени, обеспечивающие функционирование

\footnotetext{
${ }^{41}$ В большей степени объектам исключительной государственной собственности соответствует действующее поныне Приложение 3 («Перечень объектов, в отношении которых не принимаются решения о приватизации») к Основным положениям Государственной программы приватизации государственных и муниципальных предприятий в РФ после 1 июля 1994 г., утв. Указом Президента РФ от 22 июля 1994 г. № 1535 (С3 РФ.1994. № 13. Ст. 1478).

${ }^{42}$ См. ст. 2, 5, 17 Федерального закона от 21 ноября 1995 г. № 170-Ф3 «Об использовании атомной энергии»// С3 РФ. 1995. № 48. Ст. 4552; постановление Правительства РФ от 30 июня 1998 г. № 681 «Об утверждении перечня наркотических средств, психотропных веществ и их прекурсоров, подлежащих контролю в Российской Федерации» // С3 РФ. 1998. № 27. Ст. 3198.

${ }^{43}$ См. ч. 1 ст. 5 Федерального закона от 2 мая 1997 г. № 76-Ф3 «Об уничтожении химического оружия» // СЗ РФ. 1997. № 18. Ст. 2105.

${ }^{44}$ См. ч. 2 ст. 5 Федерального закона «Об использовании атомной энергии» // С3 РФ. 1995. № 48. Ст. 4552; Приложение № 1 к указу Президента РФ от 27 апреля 2007 г. № 556 «О реструктуризации атомного энергопромышленного комплекса Российской Федерации» // С3 РФ. 2007. № 18. Ст. 2185.

${ }^{45}$ См. ч. 2 ст. 5 Федерального закона от 14 февраля 2009 г. № 22Ф3 «О навигационной деятельности» // СЗ РФ. 2009. № 7. Ст. 790.
} 


\section{Право и политика $6(162) \cdot 2013$}

Государственной службы времени, частоты и определения параметров вращения Земли ${ }^{46}$;

8. иные объекты, прямо указанные в законодательных актах специального характера.

Таким образом, к объектам, которые могут находиться сугубо в государственной собственности, отнесено не только имущество, которое часто именуется общественным достоянием, но и имущество, обеспечивающее безопасность, обороноспособность, стратегические и иные интересы государства.

Изъятие определенного публичного имущества из оборота либо установление ограничений его оборотоспособности, как правило, сопровождается установлением ряда публичных требований к его содержанию, производству, контролю за использованием и т. д. Вместе с тем деление имущества по признаку оборотоспособности по сути также частноправовое. Еще со времен римского права принадлежность к res extra commercium или к res in commercio отражала способность быть предметом гражданско-правовых сделок, т. е. так называемую пассивную правоспособность вещей. Представляется, что изъятие определенных категорий имущества из оборота - это не причина появления специфического правового режима, а скорее следствие. Причина же кроется в сфере публичного права и заключается в охране и обеспечении особых государственных (общественных) интересов, а также формировании и сохранении необходимой для этого имущественной базы.

Таким образом, пожалуй, все традиционные частноправовые классификации вещей практически ничего не дают для публично-правовой науки, поскольку они характеризуют гражданско-правовые режимы имущества. Такие классификации не раскрывают связи тех или иных категорий объектов с публичными функциями и не могут служить достаточным основанием для дифференциации управления публичным имуществом, так как не отражают целей использования объектов, а следовательно, не способны сориентировать публичную администрацию и упорядочить ее деятельность. К примеру, мы можем классифицировать имущество образовательного учреждения по различным частноправовым критериям, но вряд ли это принесет ощутимую пользу для целей организации управления и достижения при этом публичного интереса. Вместе с тем такая категория как назначение имущества (в приведенном примере обеспечение предоставления образовательных услуг), находящаяся за пределами гражданского законодательства, дает достаточно ясное представление о том, зачем соответствующий объект находится в собственности государства или муниципалитета с точки зрения

${ }^{46}$ См. ст. 9 Федерального закона от 3 июня 2011 г. № 107-Ф3 «Об исчислении времени» // С3 РФ. 2011. № 23. Ст. 3247. стоящих перед ними задач и каким образом он должен управляться и использоваться.

С учетом сказанного гражданско-правовая классификация имущества представляется полезной для анализа статики отношений публичной собственности, однако не достаточна для того, чтобы «запустить» механизм публичного управления и раскрыть динамику отношений публичной собственности.

\section{4. Публично-правовая классификация публичного имущества}

Дифференциация публично-правового режима государственного и муниципального имущества основывается в России на различных критериях, таких как уровень собственности (федеральное, региональное, муниципальное имущество), естественные свойства объектов (лесные участки, водные объекты, земельные участки, здания, имущественные комплексы, ценные бумаги и др.), сфера использования и характер целевого назначения имущества и др.

В зарубежных правопорядках публичные домены (публичные вещи), также классифицируется по разным основаниям: имущество естественного и искусственного происхождения, движимое и недвижимое и т. д. Однако, пожалуй, основным критерием для дифференциации правового режима объектов собственности выступает их целевое назначение и порядок использования (имущество общего пользования, имущество публичных служб и др.). Причем данный критерий применяется не только в правовых системах, где существует институт публичной собственности (например, во Франции) ${ }^{47}$, но и там, где он официально не признан - применительно к дифференциации правового режима публичный вещей (к примеру, в Германии) ${ }^{48}$.

Механическое перенесение зарубежного опыта в российскую действительность вряд ли возможно и необходимо. Вместе с тем некоторые доктринальные подходы могли бы быть учтены. Представляется, что именно целевое назначение имущества, отражающее тот или иной публичный интерес, способно снабдить деятельность государственной и муниципальной администрации требуемым вектором и достаточной «энергией для движения». Таким образом, решающее значение имеет «прикрепление» имущества к определенной публичной функции и постановка цели использования, в результате чего появляется динамика отношений государственной и

\footnotetext{
${ }^{47}$ См., например: Lavialle Cr. Op. cit. P. 73-163; Godfrin Ph. Op. cit. P. 86-177; Auby J.-M., Bon P., Auby J.-B. Op. cit. P. 91-148.

${ }^{48}$ Papier H.-J. Op. cit. S. 17-38; Wolff H.J., Bachof O., Stober R, Kluth $W$. Verwaltungsrecht. Bd II. 7. Aufl. München: C.H. Beck, 2010. S. 149-153; Allgemeines Verwaltungsrecht / Hrsg. von H.-U. Erichsen und D. Ehlers. 14. Aufl. Berlin: De Gruyter, 2010. S. 866-880.
} 


\section{Государственные институты и правовые системы}

муниципальной собственности. На основе установленной цели формируется наиболее эффективный для ее достижения правовой механизм использования имущества.

Поскольку целевое назначение публичного имущества продиктовано возложенными на государство и муниципальные образования функциями, то при дифференциации объектов собственности на основе данного критерия мы имеем дело именно с публично-правовой их классификацией, раскрывающей суть и предназначение имущества.

Пользуясь предложенным критерием, представляется обоснованным произвести следующее базовое разделение публичного имущества в Российской Федерации:

1) публичное имущчество общчего пользования, к которому относятся объекты государственной и муниципальной собственности, свободно используемые (в установленных рамках) неопределенным кругом лиц без специального разрешения публичной администрации или договора с ней. Подобное специфическое имущество, вписанное в публичное пространство, призвано обеспечивать реализацию неотъемлемых прав и свобод личности. Именно рассматриваемая категория имущества стала основой для развития феномена публичной собственности (domaine public) во Франции, Испании и других странах, где была принята соответствующая доктрина ${ }^{49}$, а также для формирования особого института публичных вещей (öffentlichen Sachen) в Германии, Швейцарии и некоторых иных государствах ${ }^{50}$. На сегодня публичное имущество общего пользования трактуется в романо-германском праве в качестве самостоятельной и наиболее характерной разновидности публичных доменов или публичных вещей; при этом правовое регулирование соответствующих отношений в наибольшей степени изъято из сферы частного права и включено в предмет административноправовой регламентации.

С точки зрения действующего российского законодательства к данному имуществу необходимо отнести: (1) автомобильные дороги общего пользования; (2) земельные участки и территории общего пользования; (3) водные объекты общего пользования; (4) лесные участки - в части пребывания граждан в лесах и общего лесопользования); (5) объекты животного мира - в рамках установленных видов свободного пользования и т.д.

2) публичное имущество, обеспечивающее индивидуальные экономические потребности, - объекты государственной и муниципальной собственности, специально предназначенные для предоставления частным лицам для удовлетворения их экономических потребностей в соответствующем имуществе: (1) объекты государственной и муниципальной собственности, изъятые или ограничен-

${ }^{49}$ См., например: Auby J.-M., Bon P., Auby J.-B. Op. cit. P. 28-31.

${ }^{50}$ См., например: Allgemeines Verwaltungsrecht/ Hrsg. von H.-U. Erichsen und D. Ehlers. S. 866-870. ные в обороте в силу особого публичного значения, способные удовлетворять частные экономические потребности за счет ограниченного использования: участки лесного фонда, водные объекты и другие природные ресурсы в рамках специального природопользования и др.; (2) не подлежащая отчуждению имущественная инфраструктура поддержки определенных категорий лиц: нуждающихся, субъектов малого и среднего предпринимательства, социально ориентированных некоммерческих организаций и т. п.; (3) объекты, временно не обеспечивающие другие государственные и муниципальные функции и потому направленные на удовлетворение экономических потребностей частных лиц, и т. д.;

3) публичное имущество, обеспечивающее предоставление публичных услуг, - находящиеся в государственной и муниципальной собственности объекты социальной инфраструктуры (имущественные комплексы учреждений здравоохранения, образования, науки, культуры, социального обеспечения и т. д.), функционирование и финансирование которых обязаны обеспечить Российская Федерация, ее субъекты и муниципальные образования независимо от наличия объектов сопоставимого назначения в частном секторе. Появление данной категории публичного имущества - это результат определенной эволюции государственно-правовых институтов; соответствующее имущество некоммерческого использования призвано обеспечить реализацию целого спектра субъективных публичных прав граждан и организаций, которые гарантировало государство, позиционирующее себя как социальное;

4) публичное имущество, обеспечивающее общезначимую экономическую деятельность, - находящиеся в государственной и муниципальной собственности пакеты акций, имущественные комплексы унитарных предприятий и учреждений, объекты, переданные иным подконтрольным публичному образованию организациям, на основе которых осуществляются публично значимые виды деятельности общеэкономического значения, не относящиеся к государственным и муниципальным услугам: (1) энергетическая, транспортная, финансовая, информационная и иная инфраструктура; (2) финансовая инфраструктура; (3) объекты оборонной промышленности; (4) ядерный энергопромышленный комплекс; (5) нефтегазовый комплекс и т. д.

5) публичное имущчество, обеспечивающее иную публично значимую деятельность (имущество военного назначения, государственные материальные резервы, публичное имущество «аппаратного» назначения и т. д.).

Представляется, что именно предложенная классификация публичного имущества предполагает формирование принципиально различных правовых режимов соответствующих разновидностей объектов собственности с точки зрения форм их использования и механизмов 


\section{Право и политика $6(162) \cdot 2013$}

управления, а следовательно, могла бы лечь в основу закона о государственном и муниципальном имуществе, процесс разработки которого в настоящее время практически приостановлен несмотря на многочисленные призывы науки и запросы практики. По нашему убеждению, соответствующий нормативный акт, с учетом зарубежного опыта, должен выступить основой для формирования сферы специального регулирования, относящейся преимущественно к публичному праву.

\section{Библиография:}

1. Allgemeines Verwaltungsrecht/ Hrsg. von H.-U. Erichsen und D. Ehlers. 14. Aufl. Berlin: De Gruyter, 2010.

2. Auby J.-M., Bon P., Auby J.-B. Droit administratif des biens. 4e éd. P.: Dalloz, 2003.

3. Biermann J. Die öffentlichen Sachen. Giessen, 1905.

4. Biermann M. Das Staatseigentum an öffentlichen Sachen im Gemeingebrauch in der ersten Hälfte des 19. Jahrhunderts: die Theorie des reinen Hoheitsrechts an den öffentlichen Sachen von Rudolph von Jhering und Friedrich Ludwig Keller im Zusammenhang mit dem Baseler Schanzenstreit von 1859/62. Frankfurt am Main: Peter Lang, 2009.

5. Centofanti N. I beni pubblici: tutela amministrativa e giurisdizionale. Milano: Giuffrè Editore, 2007.

6. David-Beauregard-Berthier O. de. Droit administratif des biens. 6e éd. P.: Gualino, 2010.

7. Derecho de los bienes públicos / Dir. Julio V. González García. $2^{\text {a }}$ ed. Valencia: Tirant lo Blanch, 2009.

8. Derecho de los bienes públicos. 4 Tomos / Dirs. L. Parejo Alfonso, A. Palomar Olmeda. Madrid: Editorial Aranzadi, S. A., 2009Gaudemet Y. Traité de droit administrative. T. 2. Droit administratif des biens. 13e éd. P.: Librairie générale de droit et de jurisprudence (L.G.D.J), 2008.

9. Godfrin Ph. Op. cit.; Peiser G. Droit administratif des biens. 18e éd. P.: Dalloz, 2005.

10. Guettier Ch. Droit administratif des biens. P.: Presses Universitaires de France, 2008.

11. Fernández de Velasco R. Naturaleza jurídica del dominio público, según Hauriou. Aplicacióna la legislación espanola // Revista de Derecho Privado. 1921.

12. Häfelin U., Müller G., Uhlmann F. Allgemeines Verwaltungsrecht. 6. Aufl. Zürich: Dike Verlag AG, 2010.

13. Hauriou M. Précis de Droit Administratif et de droit public general. 4e éd. París: L. Larose, 1900.

14. Jiménez Blanco Carrillo A. Cuadernos de Derecho para Ingenieros. Derecho de bienes públicos. Madrid: La Ley, 2009.

15. Lavialle Cr. Droit administratif des biens. P.: Presses Universitaires de France, 1996.

16. Morand-Deviller J. Droit administratif des biens. 6e éd. P.: Montchrestien, 2010.
17. Morillo-Velarde Pérez J.I. Dominio Público. Madrid: Trivium, 1992.

18. Papier H.-J. Recht der öffentlichen Sachen. 3. Aufl. Berlin: De Gruyter, 1998.

19. Proudhon J.-B.-V. Traité du domaine public, ou de la Distinction des biens considérés principalement par rapport au domaine public. 5 vol. Dijon: Chez Victor Lagier, 1833-1834.

20. Rose C.M. Romans, Roads, and Romantic Creators Traditions of Public Property in the Information Age // Law and Contemporary Problems. 2003. Vol. 66.

21. Sánchez Morón M. Los bienes públicos (régimen jurídico). Madrid: Tecnos, 1997.

22. Vergara Blanco A.Panorama general del Derecho Administrativo Chileno // El Derecho Administrativo Iberoamericano (Estudios y Comentarios, № 9) / Dir. S. González-Varas Ibáñez, Coord. F. Villalba Pérez. Granada (España): Instituto Nacional de Administración Pública, Unión Iberoamericana de Municipalistas, 2005.

23. Wolff H. J., Bachof O., Stober R. Verwaltungsrecht. Bd II. 6. Aufl. München, 2000.

24. WolffH.J., BachofO., Stober R, Kluth W. Verwaltungsrecht. Bd II. 7. Aufl. München: C.H. Beck, 2010.

25. Азаревич Д.И. Система римского права: Университетский курс. Т. І. СПб., 1897.

26. Анненков К.Н. Система русского гражданского права. Т. 1: Введение и общая часть. СПб., 1899.

27. Барон Ю. Система римского гражданского права. Вып. 1. Кн. І: Общая часть / Пер. Л. Петражицкого. М., 1898.

28. Винницкий А.В. Государственная собственность в административном праве. М., 2010.

29. Винницкий А.В. О необходимости законодательного закрепления института юридических лиц публичного права // Журнал российского права. 2011. № 5.

30. Гинс Г.К. Право на предметы общего пользования (к проблеме взаимоотношений общих и частных интересов в гражданском праве) // Известия Юридического Факультета в г. Харбине. Т. 1. Харбин, 1925.

31. Голубцов В.Г. Сочетание публичных и частных начал в регулировании вещных отношений с участием государства. СПб., 2005.

32. Гражданское право. В 4 т. Т.2: Вещное право. Наследственное право. Исключительные права. Личные неимущественные права: Учеб. / Под ред. Е.А. Суханова. М. 2008.

33. Гримм Д.Д. Лекции по догме римского права. СПб., 1916.

34. Дернбург Г. Пандекты. Т. 1: Общая часть / Пер. Г. фон Рехенберга, под рук. и ред. П. Соколовского. М., 1906.

35. Дювернуа Н.Л. Чтения по гражданскому праву. Т. 2: Учение о вещах. Учение о юридической сделке / Под ред. и с предисл. В.А. Томсинова. М., 2004. 
36. Дюги Л. Конституционное право. Общая теория государства / Пер. А. Ященко, В. Краснокутского, Б. Сыромятникова, с предисл. к рус. пер. П. Новгородцева. М., 1908.

37. Евтихиев И.И. Теория публично-вещного права (обзор литературы) // Вопросы административного права. Кн. I / Под ред. А.И. Елистратова. М., 1916.

38. Елистратов А.И. Основные начала административного права. М., 1914.

39. Ельяшевич В.Б. Юридическое лицо, его происхождение и функции в римском частном праве. СПб., 1910.

40. Зом Р. Институции. История и система римского гражданского права. Ч. 2: Система. Вып. І: Общая часть и вещное право / Пер. Н. Кесслер; под. ред. А.Н. Беликова. Сергиев Посад, 1916.

41. Иванов А.А. Общее (народное) достояние и право государственной собственности // Правоведение. 1990. № 5.

42. Карадже-Искров Н.П. Публичные вещи. Вып. 1. Иркутск, 1927.

43. Мазаев В.Д. Публичная собственность в России: конституционные основы. М., 2004.

44. Мозолин В.П. Право собственности в Российской Федерации в период перехода к рыночной экономике. М., 1992.

45. Римское частное право: Учеб. / Под ред. И.Б. Новицкого, И.С. Перетерского. М., 2004/

46. Победоносцев К.П. Курс гражданского права. Первая часть: Вотчинные права. М., 2002.

47. Право собственности: актуальные проблемы / Отв. ред. В.Н. Литовкин, Е.А. Суханов, В.В. Чубаров. М., 2008.

48. Пухта Г.Ф. Курс римского гражданского права. Т. I / Пер. проф. Рудорффа. М., 1874.

49. Сосна С.А. О концепции общественного достояния // Государство и право. 1996. № 2.

50. Суханов Е.А. Правовая форма экономических отношений // Гражданское право России - частное право. M., 2008.

51. Тархов В.А., Рыбаков В.А. Собственность и право собственности. М., 2007.Толстой Ю.К. Содержание и гражданско-правовая защита права собственности в СССР. М., 1955.

52. Шершеневич Г.Ф. Учебник русского гражданского права. Т. 1. М., 2005.

53. Щенникова Л.С. Вещные права в гражданском праве России. М., 1996.

54. Эннекцерус Л., Кипп Т., Вольф М. Курс германского гражданского права. Т. І. Полутом 2: Введение и общая часть / Пер. с нем. И.Б. Новицкого, Г.Н. Полянской, В.А. Альтшулера; под ред. Д.М. Генкина, И.Б. Новицкого. М., 1950 (перевод с немецкого издания 1931 г.).

\section{References (transliteration):}

1. Allgemeines Verwaltungsrecht/ Hrsg. von H.-U. Erichsen und D. Ehlers. 14. Aufl. Berlin: De Gruyter, 2010.

2. Auby J.-M., Bon P., Auby J.-B. Droit administratif des biens. 4e éd. P.: Dalloz, 2003.

3. Biermann J. Die öffentlichen Sachen. Giessen, 1905.

4. Biermann M. Das Staatseigentum an öffentlichen Sachen im Gemeingebrauch in der ersten Hälfte des 19. Jahrhunderts: die Theorie des reinen Hoheitsrechts an den öffentlichen Sachen von Rudolph von Jhering und Friedrich Ludwig Keller im Zusammenhang mit dem Baseler Schanzenstreit von 1859/62. Frankfurt am Main: Peter Lang, 2009.

5. Centofanti N. I beni pubblici: tutela amministrativa e giurisdizionale. Milano: Giuffrè Editore, 2007.

6. David-Beauregard-Berthier O. de. Droit administratif des biens. 6e éd. P.: Gualino, 2010.

7. Derecho de los bienes públicos / Dir. Julio V. González García. $2^{\text {a }}$ ed. Valencia: Tirant lo Blanch, 2009.

8. Derecho de los bienes públicos. 4 Tomos / Dirs. L. Parejo Alfonso, A. Palomar Olmeda. Madrid: Editorial Aranzadi, S. A., 2009Gaudemet Y. Traité de droit administrative. T. 2. Droit administratif des biens. 13e éd. P.: Librairie générale de droit et de jurisprudence (L.G.D.J), 2008.

9. Godfrin Ph. Op. cit.; Peiser G. Droit administratif des biens. 18e éd. P.: Dalloz, 2005.

10. Guettier Ch. Droit administratif des biens. P.: Presses Universitaires de France, 2008.

11. Fernández de Velasco R. Naturaleza jurídica del dominio público, según Hauriou. Aplicacióna la legislación española // Revista de Derecho Privado. 1921.

12. Häfelin U., Müller G., Uhlmann F. Allgemeines Verwaltungsrecht. 6. Aufl. Zürich: Dike Verlag AG, 2010.

13. Hauriou M. Précis de Droit Administratif et de droit public general. 4e éd. París: L. Larose, 1900.

14. Jiménez Blanco Carrillo A. Cuadernos de Derecho para Ingenieros. Derecho de bienes públicos. Madrid: La Ley, 2009.

15. Lavialle Cr. Droit administratif des biens. P.: Presses Universitaires de France, 1996.

16. Morand-Deviller J. Droit administratif des biens. 6e éd. P.: Montchrestien, 2010.

17. Morillo-Velarde Pérez J.I. Dominio Público. Madrid: Trivium, 1992.

18. Papier H.-J. Recht der öffentlichen Sachen. 3. Aufl. Berlin: De Gruyter, 1998.

19. Proudhon J.-B.-V. Traité du domaine public, ou de la Distinction des biens considérés principalement par rapport au domaine public. 5 vol. Dijon: Chez Victor Lagier, 1833-1834.

20. Rose C.M. Romans, Roads, and Romantic Creators Traditions of Public Property in the Information Age // Law and Contemporary Problems. 2003. Vol. 66. 


\section{Право и политика 6 (162) • 2013}

21. Sánchez Morón M. Los bienes públicos (régimen jurídico). Madrid: Tecnos, 1997.

22. Vergara Blanco A.Panorama general del Derecho Administrativo Shileno // El Derecho Administrativo Iberoamericano (Estudios y Comentarios, № 9) / Dir. S. González-Varas Ibáñez, Coord. F. Villalba Pérez. Granada (España): Instituto Nacional de Administración Pública, Unión Iberoamericana de Municipalistas, 2005.

23. Wolff H. J., Bachof O., Stober R. Verwaltungsrecht. Bd II. 6. Aufl. München, 2000.

24. WolffH.J., BachofO., Stober R, Kluth W. Verwaltungsrecht. Bd II. 7. Aufl. München: C.H. Beck, 2010.

25. Azarevich D.I. Sistema rimskogo prava: Universitetskiy kurs. T. I. SPb., 1897.

26. Annenkov K.N. Sistema russkogo grazhdanskogo prava. T. 1: Vvedenie i obschaya chast'. SPb., 1899.

27. Baron Yu. Sistema rimskogo grazhdanskogo prava. Vyp. 1. Kn. I: Obschaya chast' / Per. L. Petrazhickogo. M., 1898.

28. Vinnickiy A.V. Gosudarstvennaya sobstvennost' v administrativnom prave. M., 2010.

29. Vinnickiy A.V. O neobhodimosti zakonodatel'nogo zakrepleniya instituta yuridicheskih lic publichnogo prava // Zhurnal rossiyskogo prava. 2011. № 5.

30. Gins G.K. Pravo na predmety obschego pol'zovaniya (k probleme vzaimootnosheniy obschih i chastnyh interesov v grazhdanskom prave) // Izvestiya Yuridicheskogo Fakul'teta v g. Harbine. T. 1. Harbin, 1925.

31. Golubcov V.G. Sochetanie publichnyh i chastnyh nachal $\mathrm{v}$ regulirovanii veschnyh otnosheniy s uchastiem gosudarstva. SPb., 2005.

32. Grazhdanskoe pravo. V 4 t. T.2: Veschnoe pravo. Nasledstvennoe pravo. Isklyuchitel'nye prava. Lichnye neimuschestvennye prava: Ucheb. / Pod red. E.A. Suhanova. M. 2008.

33. Grimm D.D. Lekcii po dogme rimskogo prava. SPb., 1916.

34. Dernburg G. Pandekty. T. 1: Obschaya chast' / Per. G. fon Rehenberga, pod ruk. i red. P. Sokolovskogo. M., 1906.

35. Dyuvernua N.L. Chteniya po grazhdanskomu pravu. T. 2: Uchenie o veschah. Uchenie o yuridicheskoy sdelke / Pod red. i s predisl. V.A. Tomsinova. M., 2004.

36. Dyugi L. Konstitucionnoe pravo. Obschaya teoriya gosudarstva / Per. A. Yaschenko, V. Krasnokutskogo, B. Syromyatnikova, s predisl. k rus. per. P. Novgorodceva. M., 1908.
37. Evtihiev I.I. Teoriya publichno-veschnogo prava (obzor literatury) // Voprosy administrativnogo prava. Kn. I / Pod red. A.I. Elistratova. M., 1916.

38. Elistratov A.I. Osnovnye nachala administrativnogo prava. M., 1914.

39. El'yashevich V.B. Yuridicheskoe lico, ego proishozhdenie i funkcii v rimskom chastnom prave. SPb., 1910.

40. Zom R. Institucii. Istoriya i sistema rimskogo grazhdanskogo prava. Ch. 2: Sistema. Vyp. I: Obschaya chast' i veschnoe pravo / Per. N. Kessler; pod. red. A.N. Belikova. Sergiev Posad, 1916.

41. Ivanov A.A. Obschee (narodnoe) dostoyanie i pravo gosudarstvennoy sobstvennosti // Pravovedenie. 1990. № 5.

42. Karadzhe-Iskrov N.P. Publichnye veschi. Vyp. 1. Irkutsk, 1927.

43. Mazaev V.D. Publichnaya sobstvennost' v Rossii: konstitucionnye osnovy. M., 2004.

44. Mozolin V.P. Pravo sobstvennosti v Rossiyskoy Federacii v period perehoda k rynochnoy ekonomike. M., 1992.

45. Rimskoe chastnoe pravo: Ucheb. / Pod red. I.B. Novickogo, I.S. Pereterskogo. M., 2004/

46. Pobedonoscev K.P. Kurs grazhdanskogo prava. Pervaya chast': Votchinnye prava. M., 2002.

47. Pravo sobstvennosti: aktual'nye problemy / Otv. red. V.N. Litovkin, E.A. Suhanov, V.V. Chubarov. M., 2008.

48. Puhta G.F. Kurs rimskogo grazhdanskogo prava. T. I / Per. prof. Rudorffa. M., 1874.

49. Sosna S.A. O koncepcii obschestvennogo dostoyaniya // Gosudarstvo i pravo. 1996. № 2.

50. Suhanov E.A. Pravovaya forma ekonomicheskih otnosheniy // Grazhdanskoe pravo Rossii - chastnoe pravo. M., 2008.

51. Tarhov V.A., Rybakov V.A. Sobstvennost' i pravo sobstvennosti. M., 2007.Tolstoy Yu.K. Soderzhanie i grazhdansko-pravovaya zaschita prava sobstvennosti v SSSR. M., 1955.

52. Shershenevich G.F. Uchebnik russkogo grazhdanskogo prava. T. 1. M., 2005.

53. Schennikova L.S. Veschnye prava v grazhdanskom prave Rossii. M., 1996.

54. Ennekcerus L., Kipp T., Vol'f M. Kurs germanskogo grazhdanskogo prava. T. I. Polutom 2: Vvedenie i obschaya chast' / Per. s nem. I.B. Novickogo, G.N. Polyanskoy, V.A. Al'tshulera; pod red. D.M. Genkina, I.B. Novickogo. M., 1950 (perevod s nemeckogo izdaniya 1931 g.). 